\title{
Pragmatismo e desenvolvimentismo no pensamento educacional brasileiro dos anos de 1950/1960*
}

\author{
Ana Waleska P. C. Mendonça \\ Pontifícia Universidade Católica do Rio de Janeiro, Programa de Pós-Graduação em Educação \\ Libânia Nacif Xavier \\ Universidade Federal do Rio de Janeiro, Faculdade de Educação
}

Vera Lucia Alves Breglia

Universidade Federal Fluminense, Programa de Pós-Graduação em Ciência da Informação

Miriam Waidenfeld Chaves

Universidade Federal do Rio de Janeiro, Faculdade de Educação

Maria Teresa Cavalcanti de Oliveira

Universidade Estácio de Sá, Pós-Graduação em Docência do Ensino Superior

Cecília Neves Lima

Universidade Federal do Rio de Janeiro, Faculdade de Educação

Pablo S. M. Bispo dos Santos

Universidade Federal do Rio de Janeiro, Faculdade de Educação. Universidade Estácio de Sá, Curso de Pedagogia

\section{Introdução}

Propomo-nos analisar a singular relação existente entre os ideários pragmatista e desenvolvimentista no contexto das políticas e práticas educacionais do Brasil, na década de 1950. No momento em que os países de economia periférica, como o Brasil, se ajustavam à nova lógica mundial do pós-guerra, as elites políticas e intelectuais mobilizaram-se diante do desafio de promover o desenvolvimento nacional. Nesse contexto, as políticas educacionais expressaram aproximações e distanciamentos relacionados com as diferentes concepções acerca do modelo de desenvolvimento a ser adotado.

* Este artigo vincula-se ao projeto integrado de pesquisa "O INEP no contexto das políticas do MEC, nos anos de1950/1960", desenvolvido pela PUC-Rio e pelo PROEDES (Programa de Estudos e Documentação Educação e Sociedade), da Faculdade de Educação da UFRJ, e financiado pelo CNPq. Contou também com a colaboração de Aristeo Gonçalves Leite Filho, Fernando Gouvêa, Carlos Emílio Sanches e Sandra Mara Canto.
Ao analisar as políticas do MEC (na época Ministério da Educação e Cultura), percebemos as aproximações que se deram entre dois órgãos do mesmo ministério, que se destacaram no cenário nacional daquele momento: o INEP (ná época denominado Instituto Nacional de Estudos Pedagógicos), que se ocupava para a formulação das políticas para o ensino e a pesquisa educacional, e o ISEB (Instituto Superior de Estudos Brasileiros), que assumiu papel de referência na formulação do ideário desenvolvimentista que predominou no país, naquele contexto. O INEP e o ISEB foram referências institucionais importantes para a disseminação do pragmatismo e do desenvolvimentismo, respectivamente.

Na década de 1950, a América Latina foi marcada pela gradual transformação de suas condições socioeconômicas e políticas. No bojo dessas transformações, parcela significativa de técnicos, burocratas, políticos, economistas e cientistas sociais mobilizou-se em torno do tema da aceleração e consolidação do processo de desenvolvimento econômico e social de seus respectivos países - uma mobilização conseguida pela elaboração do que se denominou de "ideário desen- 
Pragmatismo e desenvolvimentismo no pensamento educacional brasileiro dos anos de 1950/1960

volvimentista". Paralelamente, análises e propostas da recém-criada CEPAL (hoje denominada Comissão Econômica para a América Latina), órgão subordinado à ONU (Organização das Nações Unidas), passaram a enfatizar a "necessidade da utilização por parte dos governos latino-americanos de técnicas de planejamento para a implementação do desenvolvimento econômico" (Toledo, 1986, p. 225).

No Brasil, o projeto de desenvolvimento partia de temas nacionais que já vinham sendo analisados desde a década de 1930, envolvendo questões voltadas para uma política de autonomia nacional e para uma política de industrialização. Porém, nos anos de 1950, a retomada de antigas questões relacionadas ao desenvolvimento do país acabaria resultando na formulação de um conjunto de princípios que se materializariam em um amplo projeto nacional de desenvolvimento capitalista, definitivamente assumido e adotado como uma estratégia política de governo do então presidente Juscelino Kubitschek (1955-1959).

A despeito de ter sido difundido como um projeto nacional, não se constituiu em um conjunto homogêneo de idéias e soluções. Naquele contexto, o ideário desenvolvimentista que legitimava a atuação do Estado era elaborado pelos intelectuais vinculados ao ISEB, instituição que assumiu um papel de referência na concepção, orientação e divulgação do ideário desenvolvimentista brasileiro. Sua finalidade era incrementar o estudo, o ensino e a divulgação das ciências sociais, notadamente a sociologia, a história e a política, visando aplicar o instrumental teórico-metodológico dados dessas ciências à análise e à compreensão crítica da realidade brasileira, propiciando elementos teóricos capazes de permitir o incentivo e a promoção do desenvolvimento nacional (Brasil, MEC, 1960).

Genericamente visto como uma estratégia política utilizada na condução de um determinado modelo econômico para o país, o desenvolvimentismo enfatizava "a defesa da industrialização como passo estratégico para uma política de autonomia econômica e como requisito indispensável para a soberania nacional. Ainda nessa linha, defendia a nacionaliza- ção do processo econômico e a inclusão das massas urbanas na coalizão política" (Santos, 1978, p. 40).

Toledo (1986) classifica a produção intelectual do ISEB com base em cinco questões que, para ele, expressam os fundamentos básicos do ideário desenvolvimentista isebiano. Essas questões permitem identificar afinidades desse ideário com a apropriação que alguns educadores brasileiros fizeram do pragmatismo norte-americano, em sua vertente deweyana.

Os trabalhos isebianos trataram de diversas questões, embora nem todas de uma forma sistemática, rigorosa e original. [... dentre estas] podem ser destacadas as seguintes: $a$ questão da ideologia, a questão da produção científica, a questão do nacionalismo e do desenvolvimento, a questão nacional e das contradições nacionais, a questão dos intelectuais e da política. (Toledo, 1986, p. 253, grifos nossos)

Embora cada uma dessas questões apresentem abordagens específicas, constata-se, efetiva interdependência entre seus papéis e suas funções no conjunto do ideário desenvolvimentista.

De maneira geral, na lógica isebiana, a "política do desenvolvimento" era assumida como mecanismo que, articuladamente, propiciaria transformações e o efetivo desenvolvimento do país. Mas somente através da formulação de uma ideologia seria possível a elaboração de um planejamento global, necessário para se alcançar um desenvolvimento nacional efetivo e ordenado. O texto de Vieira Pinto (1960) confirma a idéia de que o projeto desenvolvimentista só se viabilizaria a partir do plano da ideologia:

O desenvolvimento é um projeto total da comunidade, é um cometimento deliberado do grupo que decide mudar as condições de existência em que se encontra e ascender a forma mais alta. [...] Logo, o desenvolvimento supõe a consciência, onde aparece primeiramente como idéia, plano de ação, antes de converter-se em cometimento social. (p. 44, grifos nossos)

Assim, de acordo com o autor, enquanto a existência da ideologia do desenvolvimento propiciaria 
um crescimento qualitativo, apoiado numa dimensão nacionalista e global, sua ausência resultaria no histórico continuísmo de um crescimento meramente quantitativo, gênese das disparidades regionais, que conseqüentemente não beneficiaria o país como um todo.

Segundo Álvaro Vieira Pinto (1960, p. 49), produção científica e produção ideológica eram entendidas como atividades articuladas e complementares, valorizando-se o papel da ciência e dos cientistas sociais nas investigações e análises dos problemas nacionais, assim como na formulação de políticas de Estado:

A ideologia deve surgir da mediação de um grupo de sociólogos, economistas e políticos que, superando o plano restrito de suas especialidades, se alcem ao pensar filosófico, por via da compreensão das categorias reais que configuram o processo histórico e acompanham o projeto de modificação das estruturas fundamentais da nação. (grifos nossos)

Do ponto de vista do ideário isebiano, a análise da questão dos intelectuais e da política é marcada pelo entendimento do conceito de "intelectual como o produtor da ideologia capaz de forjar o desenvolvimento", amparado na "realidade, que é finalmente invencível" (Kubitschek, 1956 apud Franco, 1978, p. 157). De acordo com Vieira Pinto, o intelectual é a consciência da realidade, dispondo de uma atividade racional que organiza a história, dá corpo à Nação, funda o poder. O intelectual, mediado pelo Estado, desperta a razão que prevê o futuro, encurta o tempo e preconiza o planejamento, justificando teoricamente todo esse quadro (idem, p. 158).

Nessa perspectiva, pretendemos demonstrar que o desenvolvimentismo foi um solo fértil para a retomada e expansão do pragmatismo no Brasil, pois, apesar de não se apresentar como um pensamento homogêneo, constituiu-se numa ideologia eficaz para que fosse pensado o avanço do processo de industrialização do país nos anos de 1950/1960. Foi o próprio Estado brasileiro, através do MEC, por meio do INEP e do ISEB, o lugar privilegiado para a formulação e legitimação tanto do ideário pragmatista quanto da ideologia desenvolvimentista.

Com o objetivo de mostrar o quanto o pragmatismo e o desenvolvimentismo influenciaram-se e alimentaram-se mutuamente, dividimos o presente artigo em dois blocos: o primeiro mostra de que modo a polêmica internacional em torno do pragmatismo foi assimilada em solo brasileiro; o segundo chama a atenção para as formas como o pragmatismo foi apropriado, influenciando diretamente a elaboração do Plano Nacional de Educação e a adoção do método experimental na Escola Parque - uma escola modelo na cidade de Salvador, Bahia. Por fim, as considerações finais propõem uma síntese das idéias e questões trabalhadas no texto.

\section{Pragmatismo: uma filosofia polêmica ${ }^{1}$}

No Brasil, durante os anos de 1950/1960, a mobilização em torno da modernização do país, para uns, e, para outros, a superação da situação de dependência econômica e a busca de emancipação social orientaram um conjunto de ações no âmbito do debate intelectual e da formulação de projetos de reorientação das políticas de Estado, que visavam a articulação entre industrialização, desenvolvimento científico e renovação educacional. Nesse contexto, a ideologia desenvolvimentista que pontuou o debate sobre a reestruturação econômica, política e social do país ao longo dessas duas décadas constituiu-se em um solo fértil para a retomada e a expansão do ideário da Escola Nova, e particularmente do pragmatismo deweyano entre os educadores brasileiros.

O INEP, à cuja frente se encontrava o educador Anísio Teixeira, principal expoente do pragmatismo

${ }^{1}$ Nossa fonte de inspiração para este subtítulo é um artigo recente de Cunha (2003), em que o autor se propõe a responder à pergunta "o que é pragmatismo", buscando caracterizá-lo a partir das polêmicas que o cercaram por se constituir em uma "filosofia da ação". 
deweyano no Brasil, exerceu um papel importante nesse processo, constituindo-se no principal foco de difusão do ideário pragmatista, difusão essa que se fazia não só através das suas numerosas publicações (inclusive didáticas) e dos cursos e conferências que promovia, mas também das escolas experimentais a ele vinculadas.

Por essa mesma razão, o INEP situou-se no centro de uma polêmica que, mais uma vez, confrontou os intelectuais que propunham a transformação radical do sistema educacional e a sua democratização através da escola pública com os defensores dos interesses da iniciativa privada no campo educacional, liderados pelo grupo católico, no período em estudo. ${ }^{2}$ É significativo que, nessa mesma época, nos Estados Unidos, no contexto da chamada "guerra fria", o pragmatismo se encontrava no cerne de enorme polêmica, sendo fortemente criticado à direita e à esquerda pelos seus pretensos efeitos sobre a educação norteamericana em situação de "crise". Ecos dessa polêmica chegavam até nós.

Dessa perspectiva, consideramos que o pragmatismo, no Brasil, nessa época, se situava no cerne de uma "dupla polêmica", que tinha uma dimensão internacional e uma dimensão nacional, as quais, apesar de fortemente imbricadas, guardavam suas especificidades.

Como expressão dessa polêmica na sua dimensão internacional, destacamos a publicação no Bra-

${ }^{2}$ Nos anos de 1930, católicos e liberais, que defendiam projetos diferenciados de reconstrução nacional pela via da educação, confrontaram-se em um debate acirrado que atinge o seu auge com a publicação, em 1932, por parte do segundo grupo, do "Manifesto dos Pioneiros da Educação Nova", documento emblemático da história da nossa educação. Esse debate prolongou-se por todo o processo constituinte de que se originou a Constituição Brasileira de 1934. A esse respeito, ver Xavier (2003). Na segunda metade dos anos de 1950, esse debate foi retomado, no bojo da discussão dos projetos da Lei da Diretrizes e Bases da Educação Nacional. Ver especialmente Buffa (1979). sil, em 1956, do livro A educação norte-americana em crise, pelo Editorial Vitória Ltda., editora vinculada ao Partido Comunista Brasileiro; e, em contrapartida, todo o conjunto de iniciativas promovidas pelo INEP, em 1959, ao ensejo da comemoração do centenário de nascimento de Dewey.

O livro A educação norte-americana em crise reúne um conjunto de textos de procedência e autoria diversas, incluindo uma espécie de relatório da FISE (Federação Internacional Sindical de Ensino), publicado originariamente em 1952, intitulado "A crise na educação americana", que abre o livro, propondo-se a "apresentar resumidamente um quadro da complexa e contraditória estrutura da educação nos Estados Unidos e os efeitos sobre suas condições materiais e sobre seu clima intelectual" (FISE, 1956, p. 24). Duas questões são particularmente ressaltadas nesse quadro de crise que se procura caracterizar: por um lado, o caráter discriminatório do sistema público de ensino norte-americano, apesar do discurso da igualdade de oportunidades; e, por outro, o impacto do militarismo, no contexto da chamada "guerra fria", sobre esse sistema.

A "crise" da educação norte-americana constitui-se no ponto de partida para a análise que será desenvolvida nos outros textos que compõem a obra. Particularmente, nos quatro últimos, ${ }^{3}$ procura-se vincular essa situação de crise à influência do ideário pragmatista sobre o sistema escolar norte-americano,

${ }^{3}$ São eles: "A pedagogia de John Dewey", de George Snyders, intelectual francês, ligado ao Partido Comunista, crítico implacável das pedagogias da Escola Nova; "A escola e a pedagogia norte-americana a serviço da reação”, do Prof. N. K. Gontcharov, da Academia de Ciências Pedagógicas de Moscou; "O pragmatismo na educação latino-americana”, de César Godoy Urrutia, vicepresidente da FISE; e "As tendências da filosofia contemporânea na América do Norte", de Harry K. Wells. Esses artigos são traduzidos, respectivamente, das revistas La Pensée (Revue du Rationalisme Moderne), o primeiro e o último; Sovietskaia Pedagogika, o segundo; e Aurora (Santiago do Chile), o terceiro. 
além de alertar para o risco dessa influência em outros contextos nacionais. O artigo de Snyders (1956), uma crítica bastante virulenta da pedagogia de Dewey - por ele caracterizado como "um filósofo que visa diretamente desempenhar um papel político e se coloca, para combater as forças progressistas, a serviço do grande patronato" (p.177) -, chama a atenção para a influência dessa pedagogia nas reformas do ensino secundário em marcha na França. $\mathrm{O}$ artigo de Urrutia (1956) debita à influência do pragmatismo "transplantado dos Estados Unidos da América do Norte" a situação de crise vivida pela educação chilena, caracterizando igualmente Dewey como o "filósofo da burguesia imperialista" (p. 258).

Especialmente sugestivo a esse respeito é o prefácio escrito por Paschoal Lemme, remetendo-se a um livro que teria causado "grande sensação nos meios educacionais norte-americanos", intitulado Crisis in education: a challenge to American complacency, de Bernard Iddings Bell, do qual transcreve um longo parágrafo no qual esse educador explicita sua intenção de "indagar em que extensão nossa teoria e prática educacionais são responsáveis pelo insatisfatório estado de nossa vida e cultura", e afirma peremptoriamente que "a América está progredindo para a deseducação, para impedir a educação, para prejudicar os seres humanos em desenvolvimento, para um grave perigo para a estabilidade cultural" (Bell apud Lemme, 1956, p. 12). A esse respeito, Lemme (1956, p. 12) afirma:

Tudo isso deve constituir um brado de alerta para todos nós brasileiros, e, especialmente, para os educadores. A "democracia" norte-americana e, principalmente, a educação norte-americana vêm sendo pregadas entre nós como um modelo a copiar. [...] A filosofia educacional e os métodos pedagógicos de John Dewey, especialmente a partir de 1931, foram atabalhoadamente aceitos entre nós, sem qualquer crítica, e justapostos à nossa precária organização escolar.

A partir daí, inúmeras críticas são formuladas à pedagogia deweyana, que teria, entre outras coisas, redundado num "aumento da anarquia nas escolas, justificada agora 'técnica e cientificamente"' (Lemme, 1956, p. 13). Paschoal Lemme critica alguns dos pressupostos da teoria pedagógica de Dewey, como a idéia de que a escola não é a preparação para a vida, mas a própria vida, ressaltando que ela é apenas uma parte da vida, enquanto instituição especializada na transmissão sistemática de determinados conhecimentos, alertando para os riscos da generalização do método de projetos, que viria a aumentar a fragmentação do ensino, além de chamar a atenção para o efeito nefasto da aplicação generalizada dos "testes".

Destacamos que as críticas de caráter pedagógico feitas a Dewey, no prefácio de Paschoal Lemme, extraídas do conjunto de textos publicados no livro, são extremamente semelhantes às que lhe são dirigidas pelos seus críticos à direita, como se poderá constatar a seguir.

Em 1959, por ocasião da comemoração do centenário de nascimento de Dewey, como já dissemos, uma série de iniciativas foi promovida pelo INEP. Anísio Teixeira escreve um ensaio sobre a filosofia educacional de Dewey, intitulado "Filosofia e educação", publicado na Revista Brasileira de Estudos Pedagógicos (v. 32, n. 75, p. 14-27, jul./set. 1959), republicado quase simultaneamente na revista $E d u$ cação e Ciências Sociais (v. 6, n. 12, nov. 1959), do $\mathrm{CBPE}^{4}$ (Centro Brasileiro de Pesquisas Educacionais), e sendo ainda parcialmente reproduzido no Boletim da CAPES, ${ }^{5}$ de dezembro do mesmo ano, com o título "Dewey e a filosofia da educação". Além disso,

${ }^{4}$ O CBPE foi um órgão vinculado ao INEP, criado por Anísio Teixeira em 1955, com o objetivo, entre outros, de dar maior autonomia e agilizar as iniciativas do INEP. Seus objetivos particulares praticamente reproduziam os objetivos gerais do INEP. A esse respeito, ver Brandão e Mendonça (1997) e Xavier (2003).

${ }^{5}$ A CAPES (Coordenação de Aperfeiçoamento do Pessoal de Nível Superior), atualmente estruturada como fundação, foi criada em 1951 na forma de campanha, para promover a expansão e desenvolvimento dos estudos pós-graduados no país. Vinculada inicialmente ao INEP, que era seu órgão executivo, teve à sua frente, de 1951 a 1964, o educador Anísio Teixeira, acumulando as fun- 
Pragmatismo e desenvolvimentismo no pensamento educacional brasileiro dos anos de 1950/1960

Anísio promove a reedição de várias obras de Dewey, traduzidas para o português: Como pensamos, Vida e educação, Reconstrução em filosofia, Educação e democracia, A criança e o currículo e Interesse e esforço.

Por sua vez, Jayme Abreu, colaborador de Anísio Teixeira como diretor da Divisão de Estudos e Pesquisas Educacionais do CBPE, escreve outro ensaio intitulado "A escola como agente de mudança cultural”, publicado em Educação e Ciências Sociais (v. 6, n. 12, p. 27-56, nov. 1959), no qual, a partir de uma visão panorâmica das principais tendências da filosofia da educação contemporânea, defende o ponto de vista de que apenas uma escola fundamentada na filosofia progressivista de Dewey pode vir a se constituir em agente de mudança cultural. Esse artigo foi republicado na revista Anhembi (v. 40, n. 118, p. 1435, set. 1960) e na revista venezuelana Política (n. 5, p. 16-39, jan. 1960). Abreu publica ainda, na Revista Brasileira de Estudos Pedagógicos (v. 34, n. 80, p. 155-157, out./dez. 1960), o artigo "Atualidade de John Dewey". Beatriz Osório, técnica da Divisão de Estudos e Pesquisas Educacionais do CBPE, publica, na mesma Revista Brasileira de Estudos Pedagógi$\cos$ (v. 33, n. 78, p. 8-16, abr./jun. 1960), resenha do livro de Dewey, recém-reeditado, Democracia e educação.

Em dezembro de 1959, o CBPE promove uma série de conferências em sua sede, no Rio de Janeiro, proferidas pelo Dr. Harold Benjamin, professor emérito de educação do George Peabody College for Teachers, de Nashville, Tennesse, renomado especialista em educação comparada, sobre o tema: "O papel da escola pública no Estado democrático", nas quais a filosofia de Dewey se constitui em um dos eixos centrais. O ciclo de conferências foi inaugurado pelo Professor George S. Counts, ao lado de William H. Kilpatrick, uma das lideranças do chamado progressivismo educacional. As duas conferências

ções de secretário-geral da CAPES e de diretor do INEP. A esse respeito, ver Mendonça (2002). proferidas por Harold Benjamin, precedidas de uma anterior conferência sua sobre John Dewey, com o título "A influência de John Dewey sobre a prática educacional", apresentada na Universidade Southern Illinois em março de 1959, como parte também das comemorações pelo centenário do filósofo e educador norte-americano, foram publicadas em 1960 pelo CBPE em edição bilíngüe (português/inglês) com o título A educação e o ideal democrático, com tradução de Beatriz Osório.

Por iniciativa do Centro Regional de Pesquisas Educacionais de Recife, ${ }^{6}$ foi publicada a conferência ali pronunciada por Newton Sucupira, prefaciada por Gilberto Freyre, diretor do referido Centro, com o título "Jonh Dewey: uma filosofia da experiência". Na forma de artigo, essa conferência foi igualmente publicada na Revista Brasileira de Estudos Pedagógicos (v. 34, n. 80, p. 155-157, out./dez. 1960).

Finalmente, o CBPE, com a cooperação da Fullbright Comission do Brasil, trouxe, em agosto de 1960, para realizar um ciclo de conferências no Centro Regional de Pesquisas Educacionais de São Paulo e no CBPE no Rio de Janeiro, o professor John S. Brubacher, da Universidade de Yale, também desenvolvendo o tema da filosofia educacional de John Dewey. O conjunto dessas conferências foi igualmente publicado pelo CBPE, em 1961, mais uma vez em edição bilíngüe, com tradução de Beatriz Osório, com o título A importância da teoria em educação. O texto anteriormente referido de Jayme Abreu, "Atualidade de John Dewey”, foi incorporado como prefácio a esse livro.

Cumpre destacar que, de uma forma geral, esses trabalhos estão marcados por um tom claramen-

${ }^{6}$ O CBPE foi criado juntamente com uma rede constituída por cinco centros regionais de pesquisa a ele vinculados, estrategicamente localizados nas capitais dos seguintes estados: São Paulo, Minas Gerais, Pernambuco, Bahia e Rio Grande do Sul. Esses centros reproduziam, em sua estrutura e em seus objetivos, a proposta do CBPE. A esse respeito, ver as obras já citadas de Brandão e Mendonça (1997) e Xavier (2003). 
te defensivo. Harold Benjamin, particularmente na primeira parte do livro, que corresponde à conferência sobre a influência de Dewey na prática educacional, começa por afirmar o alcance dessa influência sobre as pessoas ligadas à escola nos Estados Unidos e no Canadá, bem como sobre muitas das lideranças educacionais de vários países em distintos continentes. Ressalta particularmente essa influência de Dewey como professor, formador de gerações de professores:

A primeira e provavelmente mais facilmente observável maneira pela qual o professor Dewey influenciou a prática educacional foi em seu papel como mestre de professores de teoria educacional. William H. Kilpatrick, John L. Childs, George S. Counts e William W. Brickman, para mencionar apenas alguns dos muitos que poderiam ser arrolados, foram alunos ou colegas de Dewey, ou ambas as coisas. Eles, por seu turno, afetaram profundamente o curso da evolução educacional, através dos muitos milhares de professores e administradores que ajudaram a formar, para servir nas escolas. (Benjamin, 1960, p. 29)

Por essa razão, Benjamin chega a afirmar que "nenhum outro professor na história americana teve uma influência tão poderosa, tão duradoura e tão larga no campo inteiro da educação como a teve esse tímido, simples e esguio filho de Vermont" (idem, p. 30).

Logo a seguir, entretanto, coloca uma série de ressalvas sobre o alcance dessa influência, começando por relativizar o papel da Escola-Laboratório de Chicago. Ele estranha "o fato de que alguns dos mais vociferantes opositores às idéias educacionais de Dewey $[\ldots]$ em geral the imputam maior influência do que o faz a maioria dos seus próprios discípulos" (idem, p. 31). E surpreende-se que seja possível ainda encontrar cidadãos, pertencentes a distintas correntes culturais,

[...] que acreditam ter sido Dewey pessoalmente responsável por todos os pecados e atribulações que têm feito o país sofrer durante os últimos sessenta anos, pela alta incidência de deliqüência juvenil que se seguiu às guerras mundiais e que acompanhou o período de depressão, como pela política exterior do New Deal, ou pela crescente carga de excedentes agrícolas financiados pelo governo. (idem, p. 31)

Benjamin lamenta, ironicamente, que seja "um clichê comum, mesmo entre certos possuidores do grau de doutor em filosofia, que toda criança a quem é permitido aprender está sendo empurrada estrada abaixo na direção de um inferno intelectual, senão de um inferno moral, pelas mãos de John Dewey" (idem, p. 31). E, numa ardorosa defesa de Dewey, ressalta o caráter essencialmente liberal do seu pensamento, chamando a atenção para a íntima associação entre liberalismo e experimentalismo. Esta é uma questão central para o encaminhamento do tema das duas outras conferências, nas quais ele vai defender a necessidade de ajustar os respectivos sistemas de ensino às aspirações democráticas, sendo para isso fundamental escutar e esclarecer o povo a respeito dessa questão.

Brubacher (1961) também assume explicitamente a defesa de Dewey contra seus opositores, particularmente no capítulo 3 do livro publicado pelo CBPE, significativamente intitulado "Dez equívocos a respeito da filosofia educacional de Dewey". Começa por remeter-se "às acerbas e numerosas críticas a que a educação norte-americana tem sido submetida no após-guerra, e durante os sucessivos períodos da guerra fria”, ressaltando que, se algumas críticas são bemvindas, porque decorrem de divergência de opinião, outras resultam de mal-entendidos que é preciso desfazer. "Nessa categoria [diz ele] ninguém tem sido pior interpretado que John Dewey" (p. 60).

Ao longo do seu texto, Brubacher procura desfazer uma série de equívocos a respeito da filosofia educacional de Dewey, que, a seu ver, aparecem correntemente na imprensa e na literatura periódica especializada:

1. Dewey é culpado de "pedagogia frouxa".

2. Dewey é excessivamente complacente.

3. Dewey enfraqueceu a disciplina.

4. A influência de Dewey sobre a educação é antiintelectual. 
Pragmatismo e desenvolvimentismo no pensamento educacional brasileiro dos anos de 1950/1960

5. O pragmatismo de Dewey acentua indevidamente a educação profissional.

6. Dewey exagera a singularidade do seu "programa ativo".

7. A teoria da educação de Dewey não propõe objetivos.

8. "Desenvolvimento" como objetivo da educação é algo sem sentido ou, na melhor das hipóteses, confuso.

9. A filosofia educacional de Dewey é irreligiosa.

10. A educação de Dewey é colorida pelo radicalismo social. ${ }^{?}$

Usando os próprios textos de Dewey, Brubacher procura responder a cada uma dessas críticas, para, ao final, chamar a atenção para o fato de que, na sua perspectiva, uma das fontes principais desses equívocos, decorre da identificação que se convencionou fazer entre Dewey e a "educação progressiva". Para o autor, se é inegável a ligação de Dewey com a Progressive Education Association, da qual "logo se tornou o notável porta-voz e teórico" (idem, p. 82), isso não significa que tenha falado oficialmente em nome de toda a organização. Freqüentemente, para Brubacher, "Dewey tem sido crivado de críticas que outros integrantes do movimento da educação progressiva merecem muito mais do que ele" (idem, ibidem). Conclui o capítulo afirmando que o único antídoto para os mal-entendidos a respeito de Dewey é a leitura e o estudo dos seus próprios textos; e "cumpre que os defensores de Dewey (assim como os seus antagonistas) tratem de lê-lo cuidadosamente. Se pretendem expulsar os demônios educacionais em nome de Dewey, que se certifiquem primeiro de não estarem usando o seu nome em vão" (idem, ibidem).

${ }^{7}$ À exceção dos dois últimos itens, essas são exatamente as críticas dirigidas a Dewey pelos intelectuais de esquerda. Exemplo bastante característico é o artigo de Snyders, na publicação a que fizemos referência anteriormente. No caso do último item, curiosamente, a crítica dirigida a Dewey é invertida, sendo o mesmo acusado de "burguês e de anti-revolucionário".
Exatamente esse trecho do livro de Brubacher é retomado por Jayme Abreu, no seu prefácio. Começa por lamentar o "quase anonimato" que cercou o centenário de Dewey, no Brasil. Para ele, essa "alienação" expressava:

[...] uma certa tendência neoconservadora do nosso tempo, no clima defensivo, inibido, sem imaginação nem vigor criador da guerra fria, para a qual urge sepultar o experimentalismo de Dewey, na medida em que o seu intrínseco revisionismo é "ameaça" aos beneficiários do status $q u o$, a ser conjurada por anátemas emocionais ou abafada pela conjuntura de espesso silêncio. (Abreu, 1961, p. 10)

Abreu ressalta, a esse respeito, que também "nos meios educacionais brasileiros, mesmo naqueles que a rigor não podem ser definidos como opostos a Dewey, são freqüentes as reservas ao mesmo, mais sublinhadas mesmo do que os seus extraordinários aspectos positivos" (idem, p. 13). Referindo-se a alguns dos principais críticos da filosofia educacional de Dewey, Abreu endossa a posição assumida por Brubacher, chamando a atenção para "a extensão das distorções de que essa filosofia teria sido objeto por parte do movimento denominado "educacão progressiva", o que teria levado o próprio Dewey, em Experience and education, "a submetê-lo a sérias retificações, sobretudo no exato entendimento do papel dos impulsos espontâneos na educação" (idem, p. 14).

Ao final do texto, Abreu retoma o último capítulo do livro, significativamente intitulado "Uma filosofia da educação para 'um mundo só", no qual Brubacher defende a idéia de que o científico e o pragmático são os dois únicos âmbitos a partir dos quais é possível construir entre as nações um universo comum de entendimento, para concluir da seguinte forma:

Na medida em que formas de totalitarismo político, sobrenatural, religiosos, continuarem encarando a realidade e pretendendo decidir sobre ela como se fora um sistema imutável, terminado e estático, aferrados a valores intrínsecos, não instrumentais, apegados à racionalização do pensamento e modos de vida herdados, adstritos a um acrítico 
sentido reverencial à ordem social existente, sufocados ao peso de eruditas tradições medievais, não será legítimo esperar-se o prevalecimento do universo comum do entendimento que só o científico e o pragmático podem fornecer, e que dão, justa, a medida da atualidade instrumental do pensamento de Dewey. (idem, p. 20)

Essas, sem sombra de dúvida, são idéias que norteavam a atuação do grupo de educadores que se articulava em torno de Anísio Teixeira à época, tendo o INEP como o espaço privilegiado para a sua difusão e a sua experimentação prática. Como já dissemos, isso se fazia num contexto marcado pela polêmica, e sob forte oposição, também no âmbito nacional. A hierarquia católica, particularmente, viria a se constituir numa ferrenha opositora de Anísio Teixeira, tendo inclusive, num momento crítico do confronto, pressionado o próprio presidente Juscelino Kubitschek para que demitisse o educador dos cargos que ocupava no MEC. O estopim desse confronto com a Igreja católica foi duas conferências pronunciadas por Anísio Teixeira, publicadas de início separadamente na Revista Brasileira de Estudos Pedagógicos (v. 26, n. 63, p. 3-31, 1956 e v. 26, n. 64, p. 3-27, 1956), e depois por ele incorporadas no livro Educação não é privilégio, editado pela primeira vez em 1957.

Como assinala Nunes (1994), ${ }^{8}$ desde a realização da segunda conferência, na cidade de Ribeirão Preto, em 1956, passando pela publicação do livro, em 1957, e até a promulgação da Lei de Diretrizes e Bases da Educação Nacional, em 1961, "foram pelo menos cinco anos de embates pelas revistas pedagógicas, pela imprensa, pelos encontros e conferências públicas e pelos manifestos de ambos os lados contendores" (p. 230). As questões mais polêmicas articulavam-se exatamente com propostas de Anísio Teixeira que se fundamentavam na apropriação do

${ }^{8}$ Esse texto de Clarice Nunes, incorporado à $5^{\text {a }}$ edição do livro Educação não é privilégio, de 1994, constitui-se em excelente referência para compreender-se o contexto e o desenrolar desse embate entre Anísio Teixeira e a Igreja católica. ideário deweyano. Entre elas, a municipalização do ensino, que para Anísio era expressão do processo de descentralização administrativa, corolário da sua democratização e condição da inserção da escola na "comunidade"; a defesa da escola pública renovada, universal, gratuita, laica e, por isso mesmo, democrática; e o controle do Estado sobre a qualidade do ensino e, conseqüentemente, sobre o processo de formação de professores. É significativo que Anísio Teixeira fosse justamente atacado pela sua filiação ao pensamento deweyano, caracterizado como "ateu e comunista", em virtude da sua base materialista, aliada à perspectiva evolucionista.

A esse respeito, é muito interessante a leitura do documento de defesa de Anísio, por ele mesmo anexado à primeira edição do livro Educação não é privilégio, intitulado "A Associação Brasileira de Educação e o ensino público". Trata-se de um parecer de apoio a Anísio Teixeira aprovado e assinado pelo Conselho Diretor da entidade, cuja argumentação se centra, basicamente, em três eixos: mostrar o caráter liberal das teses defendidas por Anísio, contra a acusação de "intelectual marxista" que lhe foi dirigida; descartar a idéia de que se pretendia o monopólio do Estado no campo da educação; e inocentar John Dewey da acusação de comunista, chamando a atenção para a sua fé nos pressupostos liberais e para o alcance da influência das suas idéias para além das fronteiras políticas e ideológicas.

Esse é, portanto, o contexto extremamente conturbado em que se dava, no período em estudo, a apropriação, no Brasil, do ideário pragmatista deweyano. De forma geral, pode-se afirmar que essa apropriação se fazia numa tripla perspectiva: o pragmatismo como "método científico", implicando uma determinada concepção de ciência, particularmente das ciências sociais, com ênfase na aplicação do conhecimento científico na solução dos problemas de ordem prática, como "modo de vida democrático" e como sinônimo de "experimentalismo", no âmbito da escola. Nessas duas primeiras perspectivas, o pragmatismo informou as tentativas de racionalização do sistema escolar através de uma concepção peculiar de plane- 
jamento, que se fundamentava nos estudos de comunidade e que supunha o esclarecimento da população atingida a fim de garantir a sua aceitação e continuidade. ${ }^{9} \mathrm{Na}$ terceira perspectiva, "a escola progressiva", ${ }^{10}$ experimental e não-dualista, era percebida como a única capaz de se constituir em um agente de mudança cultural e, conseqüientemente, contribuir para a formação de uma consciência comum favorável ao desenvolvimento brasileiro. Desse ponto de vista, a transformação da escola, para ajustá-la às novas condições do país, determinadas principalmente pelo avanço do processo de industrialização, e para consolidar o funcionamento da democracia liberal, constituía-se em condição indispensável para o pleno desenvolvimento nacional.

\section{Pragmatismo, planejamento educacional e experimentalismo}

Em artigo datado de 1956, sobre a educação e o conhecimento do homem pelas ciências sociais, João Roberto Moreira ${ }^{11}$ historia o processo de aproximação do campo educacional em direção ao campo científico, procurando demonstrar como o conceito de educação foi transformando-se ao longo da história. Interessante destacar as mudanças identificadas no pós-guerra, que, segundo o educador, traziam em seu bojo a formulação do conceito social de educação. Junto à necessidade de se fazer da educação escolar um meio de adaptação e uma possibilidade de recria-

\footnotetext{
${ }^{9}$ A esse respeito, ver Mendonça (1977).

${ }^{10}$ Usamos aqui o termo no sentido que lhe é atribuído por Anísio Teixeira, que o preferia ao termo Escola Nova, por ele considerado excessivamente impreciso. Além de que o termo progressiva, a seu ver, era mais expressivo de uma escola que se pretendia em processo constante e ininterrupto de atualização e mudança.

${ }^{11}$ O educador João Roberto Moreira (1912-1967) foi técnico do INEP/MEC durante a gestão de Anísio Teixeira. Foi um dos seus principais colaboradores na montagem do CBPE e o primeiro diretor da Divisão de Estudos e Pesquisas Sociais. Ver a respeito Fávero e Britto (2002).
}

ção das relações sociais numa sociedade não estável, não estratificada e de condições indefinidas, o autor retoma a contribuição de Dewey, para quem a escola pública não seria apenas uma instituição de transmissão da cultura, nem tampouco de adaptação do ser humano à sociedade existente, mas, sim, um meio de melhoria social.

Moreira (1956) destaca a contribuição original da sociologia francesa (representada por Durkheim) para o desenvolvimento da reflexão sobre as relações entre educação e sociedade. Para o autor, sua originalidade estava no fato de que, ao mesmo tempo em que reforçava a tendência estática da educação, entendida mais como resultante do que como condicionante das mudanças sociais, essa mesma sociologia, em contrapartida, contribuiu para reafirmar a posição daqueles que buscavam nas ciências sociais as bases científicas para a organização dos sistemas de ensino, visando fundamentá-los com base na realidade social, e não apenas em intenções teóricas ou ideais.

Assim, duas tendências estariam representadas nesse mesmo processo: de um lado, a tradição ideopositivista européia, ${ }^{12}$ presente nos estudos que limitavam os problemas da realidade existente, contentando-se com sua compreensão e explicação; de outro lado, os estudos norte-americanos, que tomaram essa contribuição enfatizando as possibilidades abertas pelo conhecimento científico na solução de problemas práticos, trazendo para o próprio campo da investigação científica os problemas da ação.

Nessa linha, reforçava-se o valor teórico de John Dewey e do pragmatismo no desenvolvimento da reflexão sobre os problemas educacionais, exaltando o pouco tradicionalismo das instituições norte-americanas, que, na visão do autor, mostravam-se mais capazes de mudanças, readaptações, ensaios e experiências. A conseqüência mais notável do processo descrito foi a percepção do caráter multidisciplinar da educação, que não devia ser vista apenas como um problema sociológico, mas também cultural e antropológi-

\footnotetext{
${ }^{12}$ Expressão utilizada por João Roberto Moreira.
} 
co, econômico e ecológico, psicológico e biológico, político e moral. Ao ampliar o escopo teórico da reflexão sobre os aspectos educacionais, Moreira (1956) neutralizava o domínio exclusivo da sociologia ou de qualquer outro ramo de saber científico sobre o campo da educação, ao mesmo tempo em que valorizava o seu estatuto epistemológico enquanto campo de ciência aplicada.

De outro ponto de vista, tendo como fundamento a pesquisa, o pensamento analítico, integrador e projetivo, o planejamento constituía, na visão de Jayme Abreu (1963), uma ação formulada com base nas demandas do tempo presente, cujo resultado se concretizaria para além do ajuste das necessidades imediatas, tendo na projeção de uma situação futura, racionalmente conduzida, o seu melhor efeito. Jayme Abreu justificava a relevância do planejamento, destacando as relações estabelecidas entre os índices de analfabetismo e o grau de desenvolvimento econômico. Este último poderia ser medido pela renda per capita manifestável por duplo aspecto: como bem de consumo, com efeito direto no padrão de vida, e como bem de produção, produzindo impacto direto na eficiência da produção; ou pela melhoria técnica do conjunto da força de trabalho, ou, ainda, percebido pela mobilidade social proporcionada pela educação. Nesse sentido, o planejamento representaria, para o país, um investimento de longo prazo e, no plano individual, um fator capaz de favorecer sucesso nos negócios.

Além do benefício do planejamento educacional, entendido como possibilidade de distribuição racional dos recursos humanos e materiais, viabilizada pelo conhecimento das demandas sociais e econômicas, pela definição das tarefas necessárias ao alcance dos objetivos eleitos, das condições de efetivação do plano traçado e do controle técnico de sua execução, Roberto Moreira (1963) ressalta a necessidade de esclarecimento da população atingida pelo planejamento, a fim de garantir sua aceitação e continuidade.

Era consensual, para ambos os educadores, a percepção do planejamento educacional e do desenvolvimento econômico como processos integrados e inseridos em um conjunto mais amplo de variantes inerentes ao contexto global da sociedade a que se aplicava. Considerava-se ser esta uma condição de sucesso e, ao mesmo tempo, um obstáculo à eficiência dos planos implementados, na medida em que o planejamento, encarado como um conjunto simples de regras uniformes de ação (Moreira, 1963) desligados de uma visão dialética da totalidade do processo social global (Abreu, 1963), representava um equívoco.

No artigo "O espírito científico e o mundo atual", Anísio Teixeira questiona a permanência dos dualismos entre teoria e prática, entre o racional e o empírico, entre o manual e o intelectual, entre ação e pensamento, entre o útil e o espiritual, prevendo que, com o advento das tecnologias científicas, todas aquelas partes, antes dicotômicas, seriam reintegradas em um só método: o método científico. Apesar de visualizar tal tendência, ele registrava a existência de fortes resistências frente a hábitos milenares de segregar tais atividades, exemplificando as formas sutis de dualismo entre saber científico (o dos fatos) e saber moral e social (o dos valores e fins da atividade humana). O núcleo argumentativo concentrava-se na questão da ética, ou seja, do uso da ciência segundo princípios morais. Como afirmou o educador "a ciência nos dá os meios, mas nada pode dizer sobre os fins para os quais aplicamos esses meios" (Teixeira, 1955, p. 104). Nesse sentido, Anísio defendia as idéias centrais do seu pragmatismo, que consistia na aplicação e integração cada vez mais ampla da ciência à vida.

Para Silva (1957), ${ }^{13}$ os obstáculos que se colocavam ao planejamento educacional remetiam-se ao caráter exógeno da instituição escolar brasileira, fruto do processo que se convencionou chamar de "transplantação cultural”. Para Silva, tal processo teve como resultado graves deformações e produziu um

\footnotetext{
${ }^{13}$ Geraldo Bastos Silva integrou a primeira turma do curso
} de pedagogia da antiga Faculdade Nacional de Filosofia da Universidade do Brasil. Em 1946, ingressou como inspetor de ensino no então Ministério da Educação e Saúde Pública, dedicando-se ao estudo do ensino secundário no Brasil. Ver a respeito Fávero e Britto (2002). 
desajustamento entre a escola e as condições reais do meio em que existia. Seu raciocínio baseava-se na constatação de que as instituições escolares brasileiras não eram fruto de uma formação espontânea, assim como não foram precedidas de ensaios e erros realizados no decorrer do processo transmissor de cultura, pois surgiram sem qualquer precedência orgânica e natural, foram completamente criadas e estabelecidas num meio no qual não se inseriam segundo critérios de exigências endógenas. É a atitude exemplarista - adoção literal de instituições estrangeiras, ou a crença de que o problema do Brasil como constituição de nação seria resolvido pela adoção do modelo das instituições dos países líderes.

Ao exemplarismo educacional, Silva (1957) atribuiu, à época, o fato de as instituições educacionais transplantadas não terem exercido o papel que delas se esperava em relação ao progresso econômico e social. Para ele, prevaleceram as condições econômicas de subdesenvolvimento, "que não só tornavam impraticável uma acentuada expansão quantitativa do sistema escolar, mas também, dado o fato de que a educação escolar não tinha função realmente útil e necessária a preencher, essa expansão, meramente quantitativa, tornava irrelevante o problema da qualidade e do tipo de ensino ministrado nas escolas" (Silva, 1957, p. 35).

À percepção de que a realidade brasileira era marcada por dualismos e pela resistência à mudança somava-se a questão da transplantação educacional, evidenciando, para esses educadores, os pontos de estrangulamento para a formulação de um plano de educação por meio do qual se pudesse conduzir o processo em curso no Brasil - marcado pela passagem de uma estrutura social e econômica predominantemente agrícola para uma estrutura crescentemente industrial -, levando a escola a funcionar como um instrumento de desenvolvimento.

As dificuldades de lidar com os problemas conjunturais e de infra-estrutura levariam os educadores a admitir que ficamos reféns de arcaísmos, seja de caráter pedagógico, seja pela origem das estruturas educacionais existentes, ou de ordem legislativa. Tais embaraços foram entendidos como desafios a serem enfrentados pelos educadores no ajuste às necessidades trazidas pelas "novas estruturas econômicas". Como observa Anísio Teixeira (1953), o Brasil precisava decidir sobre suas próprias instituições uma vez que ele considerava que a crise educacional configurava apenas um aspecto da crise de readaptação institucional pela qual passava o país.

Traduzindo esse ponto de vista na formulação do Plano Nacional de Educação, Anísio Teixeira propôs a completa reformulação da filosofia do sistema de ensino brasileiro. Para ele, não interessava promover apenas a expansão quantitativa do sistema de ensino, sem a reconstrução da escola e de seus objetivos. Acreditava que os esforços de reorganização do ensino deveriam concentrar-se na superação do modelo dual de escola, montado para promover a formação de elites letradas para servir ao governo, por um lado, e, por outro, formar a massa de trabalhadores pouco educados. Ao mesmo tempo em que reconhecia ser esse modelo de ensino um reflexo do arcaísmo que marcava a sociedade brasileira, Anísio Teixeira partilhava a crença propalada pelos intelectuais isebianos de que o Brasil passava por grandes transformações e que essas transformações poderiam ser canalizadas para promover o desenvolvimento do país.

A modernização econômica era o lado visível desse processo, e a educação era o móvel de consolidação do processo de mudança que, dependendo do grau de consciência nacional e do esforço de reconstrução e desenvolvimento mobilizado, poderia ser orientada não só no sentido do desenvolvimento econômico, como também no sentido da consolidação do modo de vida democrático.

A escola atuaria, assim, como espaço de construção dessa nova consciência nacional, garantindo, dessa forma, a possibilidade de se fazer permanente e progressiva a grande mobilização do esforço brasileiro (Teixeira, 1962). Sem dúvida, a percepção das dificuldades apresentava-se como o necessário conhecimento das condições objetivas da realidade brasileira. E 
foi com base nesse conhecimento que Anísio Teixeira elaborou a proposta do Plano Nacional de Educação e o seu desdobramento em planos estaduais. ${ }^{14}$

A apropriação do pragmatismo de Dewey no pensamento e na ação de Anísio Teixeira revela-se em três aspectos do referido plano. Estes falam a favor da modernização do sistema de ensino, entendida em termos de racionalização administrativa segundo uma filosofia própria, que, por sua vez, leva à defesa do modelo democrático, no âmbito da política, da vida social e da produção e apropriação dos bens culturais. Para tanto, fazia-se mister que a escola se tornasse uma instituição organizada de forma a produzir uma nova consciência, calcada na valorização do saber e na sua apropriação, por todos, como instrumento de poder, consubstanciado no poder de ação sobre o próprio destino e, por conseguinte, sobre os destinos da nação. A esse modelo de escola corresponderia, de forma mais ampla, uma política educacional adequada às necessidades da vida moderna que se pretendia instaurar.

Buscando alcançar as metas almejadas e, ao mesmo tempo, superar os obstáculos mencionados, as linhas gerais do Plano Nacional de Educação foram assim definidas: 1) prioridade para a educação primária, de forma a elevar o nível geral de educação de todo o povo; 2) centralidade da formação do magistério; 3) articulação entre o projeto de ampliação da rede escolar primária e média e de treinamento do magistério. $\mathrm{Na}$ base de sua proposta estava a perspectiva de romper com a dualidade do sistema escolar brasileiro (a escola do povo e a escola da elite) em favor do desenvolvimento da "educação mais eficiente (aprendizagem prática) em oposição à educação do tipo acadêmico ou livresco" (Teixeira, 1953, p. 34).

O desenho da nova escola concebida por Anísio Teixeira distanciava-se dos antigos padrões acadêmi-

${ }^{14}$ Com a promulgação da Lei de Diretrizes e Bases da Educação Nacional, em dezembro de 1961, coube ao Conselho Federal de Educação, que tinha Anísio Teixeira entre seus conselheiros, elaborar o Plano Nacional de Educação. cos e buscava seus próprios moldes na vida em comunidade, local onde os alunos viviam e aprendiam as artes e as relações da sociedade compósita e difícil da qual participavam. O pressuposto é que esse modelo de escola se organizasse tendo em conta a diversidade e a diversificação. Essa era a representação de um tipo de educação definida como nova, ativa, progressiva e que o mundo recém descobria e aplicava suas técnicas e seus métodos. A concretização dessa educação estaria referendada pela constatação de que "a escola tem que se fazer prática e ativa, e não passiva e expositiva, formadora, e não formalista (Teixeira, 1953, p. 42).

A construção das "escolas básicas da Nação" (primária e média) constituía prioridade no referido Plano, na medida em que representavam o eixo central da mudança no sistema escolar vigente, pela ruptura com a já mencionada duplicidade, e a possibilidade de elevar o nível geral da educação de todo o povo para criar novas condições de trabalho e de compreensão do esforço comum. Propondo "virar pelo avesso a nossa filosofia da educação" Anísio Teixeira (idem, p. 115), defendia que a escola primária era a mais importante porque dela dependeria não só a aceleração, mas a estabilidade e a consolidação do progresso até então realizado.

A adequada formação de professores, peça chave para que a reforma fosse bem sucedida, ganhou uma nova modalidade institucional: a instalação dos centros de treinamento, destinados aos que desejassem devotar-se ao magistério. ${ }^{15}$ A perspectiva orgânica também se refletia na proposta de articulação rigorosa dos estudos com a prática direta do ensino. As escolas deveriam se organizar sob a forma de escolas de demonstração, escolas experimentais e escolas de prática, com amplitude suficiente para permitir a capacitação individual. O treinamento do professor se faria pelo método do aprendizado por meio de estágios, mas também estava previsto em seminários o

${ }^{15}$ Poderiam freqüentar os referidos centros aqueles que tinham concluído os estudos de nível médio, no primeiro e segundo ciclos.

Revista Brasileira de Educação $\quad$ v. 11 n. 31 jan./abr. 2006 
debate dos problemas teóricos e práticos do ensino. A criação dos centros de treinamento, tal como Anísio Teixeira os concebeu, era instrumento fundamental para se promover a articulação entre o projeto de ampliação da rede escolar primária e média e de treinamento do magistério, garantindo, dessa forma, a tão almejada elevação da qualidade do ensino paralelamente à expansão quantitativa de suas instituições.

A retomada dos pressupostos do pragmatismo de John Dewey, aplicado às esferas da gestão e do planejamento educacional, bem como à realidade concreta das escolas, estaria também na origem do que se convencionou denominar de experimentalismo pedagógico, que consistia na aplicação do método experimental aos programas de ensino e orientações curriculares de algumas instituições criadas especificamente com essa finalidade. A partir dessas escolas experimentais, vinculadas ao CBPE e aos Centros Regionais de Pesquisa a ele articulados, pretendia-se a expansão do projeto por todo o país.

Antes de irmos ao cerne da questão que pretendemos abordar, é necessário recuperar o que Anísio Teixeira afirmava a respeito do pragmatismo deweyano:

A educação comum, para todos, já não pode ficar circunscrita à alfabetização e à transmissão mecânica das três técnicas básicas da vida civilizada - ler, escrever e contar. Já precisa formar, tão solidamente quanto possível embora em nível elementar, nos seus alunos, hábitos de competência executiva, ou seja, eficiência de ação: hábitos de sociabilidade, ou seja, interesse na companhia de outros, para o trabalho ou o recreio; hábitos de gosto, ou seja, de apreciação da excelência de certas realizações humanas (arte); hábitos de pensamento e reflexão (método intelectual); e sensibilidade de consciência para os direitos e reclamos seus e de outrem. (Teixeira, 2000, p. 107-108)

A esse respeito, é exemplar a experiência do Centro Educacional Carneiro Ribeiro, instituição pioneira no que se refere ao desenvolvimento de outras iniciativas educacionais realizadas em escolas experimentais. Criado em 1950, durante a segunda administração de Anísio Teixeira na Secretaria de Educação do
Estado da Bahia (1947-1950), consistiu em uma iniciativa de renovação pedagógica que acabou por se tornar uma referência internacional.

No que se refere ao ensino ministrado por ele, é correto afirmar que, com orientação curricular e programas de ensino fundamentados principalmente em pressupostos didático-pedagógicos estreitamente vinculados ao pragmatismo de John Dewey, seria uma experiência modelar para as iniciativas pedagógicas que Anísio Teixeira e sua equipe pretendiam desenvolver no cenário educacional brasileiro a partir de sua atuação à frente do INEP, nos anos de 1950 e 1960.

O referido Centro constituía-se em uma escola articulada em dois setores: "escola-classe" e "escolaparque". A "escola-classe" tinha como objetivo fornecer aos alunos instrução análoga à recebida em uma instituição primária regular, enquanto a "escola-parque" se destinava a fornecer conteúdos complementares, tais como formação de valores e preparação para o trabalho.

Dois aspectos relativos a essa divisão merecem ser destacados: primeiro, muito embora Anísio Teixeira tenha concebido o Centro Educacional Carneiro Ribeiro com esses dois setores, isso não implicava um ensino de caráter dualista (perspectiva freqüentemente combatida por esse educador), posto que seus alunos freqüentavam as aulas de ambos os setores; segundo, muito embora na "escola-classe" os conteúdos escolares fossem análogos aos de uma escola regular da rede pública de ensino, eram utilizadas, tanto nesse setor quanto na "escola-parque", metodologias de ensino de caráter experimental, inspiradas principalmente no pragmatismo deweyano, e particularmente no método de projetos de Kilpatrick.

Seria interessante ressaltar que aquele Centro (conhecido popularmente como Escola-Parque) o pragmatismo seria simultaneamente método de ensino e diretriz de formação ética dos alunos, o que pode ser comprovado a partir da leitura da seguinte citação:

A filosofia da escola visa oferecer à criança um retrato da vida em sociedade, com as suas atividades diversificadas e o seu ritmo de "preparação" e "execução", dando- 
lhe as experiências de estudo e de ação responsáveis. Se na escola-classe predomina o sentido preparatório da escola, na escola-parque [...] predomina o sentido de atividade completa, com as suas fases de preparo e de consumação, devendo o aluno exercer em sua totalidade o senso de responsabilidade e ação prática, seja no trabalho, que não é um exercício mas a fatura de algo completo e de valor utilitário, seja nos jogos e na recreação, seja nas atividades sociais [...]. (Teixeira, 2000, p. 165)

Tratando especificamente sobre o modo como o pragmatismo e o desenvolvimentismo se faziam presentes no âmbito do Centro Educacional Carneiro Ribeiro, cabe destacar que, dentre seus objetivos, se destacava o de preparar o aluno para as mudanças ocorridas na sociedade industrial do mundo moderno, o que pode ser comprovado pela seguinte citação:

O plano do Centro Carneiro Ribeiro [...], caso permitam as circunstâncias, a experiência em desenvolvimento em Salvador, Bahia, poderá constituir-se o passo inicial de um esforço que não seja apenas um remédio circunstancial, mas a própria solução do problema da educação primária comum no Brasil, ou seja, a necessária mudança estrutural da escola primária, para atender aos objetivos da sociedade nova que o desenvolvimento econômico acelerado virá inevitavelmente trazer, e que, só por meio do agente catalítico desse novo tipo de educação, deixará de ser uma convulsão para ser uma solução. (idem, p. 174)

No que se refere à perspectiva de formação do indivíduo pretendida pela Escola-Parque, cabe ainda mencionar que, se na dimensão ética o trabalho era o elemento mediador da mentalidade do progresso, em cuja premissa maior estaria o fato de que se tornaria necessário romper com o modo conservador de pensar as questões alusivas às relações sociais dos indivíduos, a diretriz política nela adotada, por sua vez, encaminharia para uma progressiva adequação dos alunos aos pressupostos da democracia representativa, bem como para uma visão ampla dos saberes e conhecimentos necessários para o bom desempenho do papel da cidadania, nessa perspectiva. A esse res- peito, cabe destacar que a idéia de que o conhecimento humano deveria ser difundido de forma plural no âmbito da escola primária se torna clara, na citação, em que Teixeira (2000, p. 182) concebe a educação primária naquele centro como "algo que lembra uma pequenina universidade infantill". Com isso, pode-se perceber que o Centro Educacional Carneiro Ribeiro foi, para Anísio Teixeira e para os educadores a ele associados, elemento central para o projeto de conduzir o país ao progresso, ao desenvolvimento econômico e ao modo de vida democrático pela via da educação escolar, o que se daria caso iniciativas educacionais como a desenvolvida no centro viessem a ser adotadas em larga escala no sistema nacional de ensino que os educadores à frente do INEP almejavam construir no Brasil nas décadas de 1950 e 1960.

Dessa perspectiva, pode-se afirmar que a articulação promovida entre pragmatismo e democracia representativa, verificada no Centro Educacional Carneiro Ribeiro, se relacionava, igualmente, com a ideologia desenvolvimentista, que informava a atuação das duas instituições que constituíam a essa época uma espécie de guarda avançada do MEC: o ISEB e o INEP.

\section{Considerações finais}

Como anunciamos na introdução, nossa intenção neste texto foi resgatar os ideários pragmatista e desenvolvimentista, assim como a singular relação existente entre ambos, como aspectos marcantes do contexto das políticas e práticas educacionais do Brasil dos anos de 1950. De forma paralela, foi demonstrado que parte relevante das afinidades existentes entre o ideário desenvolvimentista e a retomada do pragmatismo foi fabricada no interior do próprio Estado brasileiro; e, mais exatamente, dentro do ISEB e do INEP, órgãos do MEC, nos quais parcela importante da nossa intelectualidade se estabeleceu e, respectivamente, intensificou tanto a fermentação de um pensamento desenvolvimentista quanto a elaboração de uma política educacional com base no pragmatismo. A esse respeito, cabe salientar uma característica básica desses intelectuais: não só se empenharam na ela- 
boração de um pensamento próprio sobre as questões nacionais, como também, ocupando postos-chave na esfera governamental, possibilitaram a circulação dessas idéias no interior do próprio aparelho de Estado, influenciando, de alguma forma, as ações de governo.

Ambos os grupos faziam uma análise semelhante a respeito das causas do nosso atraso e buscavam alternativas para a sua superação. Nos dois casos, essas análises serviram de base para a elaboração de um planejamento político, econômico e educacional que objetivava a construção do moderno Estado brasileiro, nos anos em estudo. Ambos os grupos estavam interessados na reconstrução da nação por meio da criação de determinados mecanismos que propiciariam a autonomia nacional e a fermentação de uma nova atmosfera cultural no país.

Enquanto Anísio Teixeira, em seu discurso de posse no INEP, defendia que desse órgão deveria eclodir um movimento de formação de uma consciência comum, indispensável à reconstrução nacional, liase, nos estatutos do ISEB, que era objetivo desse centro pensar criticamente a realidade brasileira com o intuito de elaborar certos instrumentos teóricos que permitiriam o incentivo e a promoção do desenvolvimento nacional. Entre eles, a constituição de uma ideologia favorável ao desenvolvimento, condição indispensável à ocorrência desse processo.

Para isebianos como Vieira Pinto, a ideologia constituía-se em um sistema de idéias que direciona a ação impelindo a uma transformação; ou seja, não se tratava apenas da formulação de um sistema de idéias puro, mas da construção de um ideário que vislumbrava a passagem de um Brasil agrário, arcaico e dependente, para um Brasil industrial, moderno e desenvolvido. Para o pragmatismo também não existiria um sistema de idéias puro, mas esse sistema estaria conectado à ação por meio da experiência, que tem uma finalidade prática de incessante superação de uma situação anterior, e acaba por revestir-se de um significativo sentido político, voltado para a consolidação de uma vida social condizente com as novas exigências de uma sociedade industrial moderna e democrática.
No que diz respeito ao papel da produção científica brasileira, ambos os grupos entendiam a ciência enquanto instrumento decisivo, tanto na fundamentação da ideologia desenvolvimentista quanto na reestruturação das políticas educacionais. No campo educacional, o pragmatismo seria a expressão de maior destaque dessa abordagem científica.

\section{Referências bibliográficas}

ABREU, Jayme. Atualidade de John Dewey. In: BRUBACHER, John S. A importância da teoria em educação. Rio de Janeiro: INEP, 1961.

. Educação e desenvolvimento: uma colocação do problema na perspectiva brasileira. Revista Brasileira de Estudos Pedagógicos, Rio de Janeiro, v. 40, n. 91, p. 6-28, jul./set. 1963.

BENJAMIN, Harold R. W. A educação e o ideal democrático. Rio de Janeiro: INEP, 1960.

BRANDÃO, Zaia; MENDONÇA, Ana Waleska (Orgs.). Por que não lemos Anísio Teixeira? Uma tradição esquecida. Rio de Janeiro: Ravil, 1997.

BRASIL. Relatório qüinqüenal, 1956-1960. Brasília/DF: Ministério da Educação e Cultura, 1960.

BRUBACHER, John S. A importância da teoria em educação. Rio de Janeiro: INEP, 1961

BUFFA, Ester. Ideologias em conflito: escola pública e escola privada. São Paulo: Cortez \& Moraes, 1979.

CUNHA, Marcus Vinicius da. Pragmatismo: uma filosofia definida no campo da polêmica. Filosofia Americana, v. 1, n. 1, p. 39-48, set. 2003 .

FÁVERO, Maria de Lourdes; BRITTO, Jader de Medeiros (Orgs.). Dicionário de educadores no Brasil. 2. ed. Rio de Janeiro: Ed. da UFRJ; Brasília: MEC/INEP, 2002.

FISE - FEDERAÇÃO INTERNACIONAL SINDICAL DE ENSINO; MATTHIAS, L. L.; KENNEDY, Steton et al. A crise na educação americana. In: FEDERAÇÃO INTERNACIONAL SINDICAL DE ENSINO et al. A educação norte-americana em crise. Rio de Janeiro: Editorial Vitória, 1956. p. 23-85.

. A educação norte-americana em crise. Rio de Janeiro: Editorial Vitória, 1956. 
FRANCO, Maria Sylvia Carvalho. O tempo das ilusões. In: CHAUÍ, Marilena (Org.). Ideologia e mobilização popular. Rio de Janeiro: Paz e Terra, 1978. p.151-209.

LEMME, Paschoal. Prefácio. In: FEDERAÇÃO INTERNACIONAL SINDICAL DE ENSINO; MATTHIAS, L. L.; KENNEDY, Steton et al. A educação norte-americana em crise. Rio de Janeiro: Vitória, 1956. p. 11-15.

MENDONÇA, Ana Waleska. O CBPE: um projeto de Anísio Teixeira. In: BRANDÃO, Zaia; MENDONÇA, Ana Waleska (Orgs.). Por que não lemos Anísio Teixeira? Uma tradição esquecida. Rio de Janeiro: Ravil, 1997. p. 27-46.

. A formação dos mestres: a contribuição de Anísio Teixeira para a institucionalização da pós-graduação no Brasil. In: (Coord.). Relatório final de pesquisa. Rio de Janeiro: Departamento de Educação da PUC-Rio, 2002. 1 CDROM.

MOREIRA, João Roberto. A educação e o conhecimento do homem pelas ciências sociais. Revista Brasileira de Estudos Pedagógicos, Rio de Janeiro, v. 25, n. 62, p. 41-55, abr./jun. 1956.

. A pesquisa e o planejamento em educação. Revista

Brasileira de Estudos Pedagógicos, Rio de Janeiro, v. 39, n. 90, p. 8-23, 1963.

NUNES, Clarice. Prioridade número um para a educação popular. In: TEIXEIRA, Anísio. Educação não é privilégio. Rio de Janeiro: Ed. da UFRJ, 1994. p. 199-252.

SANTOS, Wanderley G. Ordem burguesa e liberalismo político. São Paulo: Duas Cidades, 1978.

SILVA, Geraldo Bastos. Educação e desenvolvimento nacional. Rio de Janeiro: ISEB, 1957.

SNYDERS, George. A pedagogia de John Dewey. In: FEDERAÇÃO INTERNACIONAL SINDICALDE ENSINO; MATTHIAS,

L. L.; KENNEDY, Steton et al. A educação norte-americana em crise. Rio de Janeiro: Vitória, 1956. p. 175-258.

TEIXEIRA, Anísio. A crise educacional brasileira. Revista Brasileira de Estudos Pedagógicos, Rio de Janeiro, v. 19, n. 50, p. 2043, abr./jun. 1953.

. Educação e a formação nacional do povo brasileiro. In:_._Educação não é privilégio. 6. ed. Rio de Janeiro: UFRJ, 2000. p. 113-182.
O espírito científico e o mundo atual. Revista Brasileira de Estudos Pedagógicos, Rio de Janeiro, v. 23, n. 58, p. 325, 1955.

Uma experiência de educação primária integral no

Brasil. Revista Brasileira de Estudos Pedagógicos, Rio de Janeiro, v. 38, n. 87, p. 21-28, jul./set. 1962.

TOLEDO, Caio Navarro. ISEB: fábrica de ideologias. Campinas: Ed. da UNICAMP, 1986.

URRUTIA, César Godoy. O pragmatismo na educação latino-americana. In: FEDERAÇÃO INTERNACIONAL SINDICAL DE ENSINO; MATTHIAS, L. L.; KENNEDY, Steton et al. A educação norte-americana em crise. Rio de Janeiro: Vitória, p. 243-258, 1956.

VIEIRA PINTO, Álvaro. Consciência e realidade nacional. Rio de Janeiro: ISEB, 1960. $2 \mathrm{v}$.

XAVIER, Libânia Nacif. Para além do campo educacional: um estudo sobre o Manifesto dos Pioneiros da Escola Nova. Bragança Paulista: EDUSF, 2003.

ANA WALESKA P. C. MENDONÇA, doutora em educação brasileira pela Pontifícia Universidade Católica do Rio de Janeiro (PUC-Rio), é professora do Programa de Pós-Graduação em Educação da mesma universidade e coordenadora da pesquisa: "O INEP no contexto das políticas do MEC, nos anos de 1950 e 1960", financiada pelo Conselho Nacional de Desenvolvimento Científico e Tecnológico $(\mathrm{CNPq})$, da qual se origina o presente artigo. Principais publicações: organizou, com Zaia Brandão, Por que não lemos Anísio Teixeira? Uma tradição esquecida (Rio de Janeiro: Ravil, 1997); Anísio Teixeira e a Universidade de Educação (Rio de Janeiro: EdUERJ, 2002); A pós-graduação como estratégia de reconstrução da universidade brasileira (Educar em Revista, n. 21, p. 289-308, jan.jun. 2003).E-mail: awm@edu.puc-rio.br

LIBÂNIA NACIF XAVIER, doutora em educação brasileira pela Pontifícia Universidade Católica do Rio de Janeiro (PUCRio), é professora da Faculdade de Educação da Universidade Federal do Rio de Janeiro (UFRJ) e pesquisadora do Programa de Estudos e Documentação Educação e Sociedade (PROEDES), da mesma instituição. Atualmente desenvolve a pesquisa intitulada: "Espaço Anísio Teixeira: referência para a pesquisa educacional no Brasil" e participa da pesquisa inter-institucional: "O INEP no 
Pragmatismo e desenvolvimentismo no pensamento educacional brasileiro dos anos de 1950/1960

contexto das políticas do MEC, nos anos de 1950 e 1960". Principais publicações: Para além do campo educacional: um estudo sobre o Manifesto dos Pioneiros da Educação Nova (Bragança Paulista: EDUSF, 2002) e O Brasil como laboratório: educação e ciências sociais no projeto do Centro Brasileiro de Pesquisas Educacionais - CBPE/INEP/MEC (Bragança Paulista: EDUSF, 1999). E-mail: libania.xavier@terra.com.br

VERALUCIAALVES BREGLIA, doutora em educação brasileira pela Pontifícia Universidade Católica do Rio de Janeiro (PUC-Rio), é professora adjunta do Departamento de Ciência da Informação da Universidade Federal Fluminense (UFF) e do Programa de Pós-Graduação em Ciência da Informação. Pesquisa em andamento: "O INEP no contexto das políticas do MEC, nos anos de 1950 e 1960", coordenando o subprojeto intitulado: "O acervo institucional do INEP na Biblioteca Espaço Anísio Teixeira (UFRJ): proposta de organização". E-mail: vbreglia@domain.com.br

MIRIAM WAIDENFELD CHAVES, doutora em educação brasileira pela Pontifícia Universidade Católica do Rio de Janeiro (PUC-Rio), é professora adjunta da Faculdade de Educação da Universidade Federal do Rio de Janeiro (UFRJ) e pesquisadora participante da pesquisa "O INEP no contexto das políticas do MEC, nos anos de 1950 e 1960". Entre outros artigos, publicou: A afinidade eletiva entre Anísio Teixeira e John Dewey (Revista Brasileira de Educação, São Paulo: ANPEd, n. 11, p. 86-98, maio/ago. 1999), A Revista Escola Argentina: reflexões sobre um periódico escolar anos 20 e 30 (Revista Brasileira de História da Educação, Campinas: Sociedade Brasileira de História da Educação/Autores Associados, p. 59-85, 2003).E-mail: miriamfeld@terra.com.br

MARIA TERESA CAVALCANTI DE OLIVEIRA, doutoranda em educação brasileira pela Pontifícia Universidade Católica do Rio de Janeiro (PUC-Rio), é professora do Curso de PósGraduação em Docência do Ensino Superior da Universidade Estácio de Sá e pesquisadora participante da pesquisa: "O INEP no contexto das políticas do MEC nos anos de 1950 e 1960". A tese de doutorado na qual vem trabalhando tem sido financiada pela Coordenação deAperfeiçoamento de Pessoal de Nível Superior (CAPES) e pelo Conselho Nacional de Desenvolvimento Científico e Tecnológico (CNPq), e se intitula ISEB - Instituto Superior de Estudos Brasileiros: o legado de uma intervenção político-pedagógica no contexto desenvolvimentista dos anos 50. Email: tetecavalcanti@terra.com.br

CECÍLIA NEVES LIMA, graduada em pedagogia pela Universidade Federal do Rio de Janeiro (UFRJ), bolsista de iniciação científica da Fundação Universitária José Bonifácio atuando na pesquisa: "Espaço Anísio Teixeira: referência para a pesquisa educacional no Brasil". Publicou: Ciência e arte de educar: a experiência da Escola Guatemala (monografia apresentada à Faculdade de Educação da UFRJ, em dezembro de 2004); em co-autoria com Célia Maria dos Santos Duarte, Espaço Anísio Teixeira: referência para a pesquisa educacional no Brasil (In: JORNADA DE INICIAÇÃO CIENTÍFICA, 26. Caderno de Resumos, UFRJ, 2004); em co-autoria com Amália Dias, A política de publicações do CBPE/MEC e o magistério primário no Distrito Federal (19551965) (In: JORNADA DE INICIAÇÃO CIENTÍFICA, 27. Caderno de Resumos, UFRJ, 2005).E-mail: lima_cn@hotmail.com

PABLO SILVA MACHADO BISPO DOS SANTOS, doutorando em educação brasileira na Pontifícia Universidade Católica do Rio de Janeiro (PUC-Rio), atuou como professor substituto da Faculdade de Educação da Universidade Federal do Rio de Janeiro (UFRJ) e no curso de pedagogia da Universidade Estácio de Sá. Dentre suas publicações, destacam-se: O Colégio Nova Friburgo da Fundação Getúlio Vargas: mergulhando em sua memória institucional (dissertação de mestrado apresentada ao Departamento de Educação da PUC-Rio em março de 2005); em coautoria com Aristeo Leite Filho, O INEP no contexto das políticas do MEC nos anos de 1950-1960 (In: CONGRESSO BRASILEIRO DE HISTÓRIA DA EDUCAÇÃO, 3. 1 CD-ROM). E-mail: psmbs@universiabrasil.net

Recebido em novembro de 2004 Aprovado em agosto de 2005 
Palabras claves: prácticas de lectura y escritura; tecnologías de información y comunicación; computadoras; estudiantes de enseñanza media superior; aproximación sociocultural; investigación cualitativa

O deslocamento de práticas impressas e a apropriação de práticas digitais.

Um estudo com alunos do ensino médio tecnológico aprendendo a usar o computador na escola

São apresentados os resultados de um projeto de pesquisa qualitativa centrado nas práticas de leitura e escrita de oito pares de alunos de ensino médio, que usam o computador. Com uma abordagem sociocultural, este trabalho analisa eventos alfabetizadores gravados em áudio e vídeo. As descobertas revelam como os alunos desenvolvem diversas práticas de leitura e escrita dependendo do tipo de produção e conhecimento que se requer para sua realização. Também explica como suas práticas são transformadas em processos de mudança do ambiente impresso para culturas digitais. $O$ estudo conclui que as tecnologias da informação e comunicação abrem as portas para mundos com múltiplas formas de ler e escrever, numa relação complementar com o mundo impresso. Esta situação leva a considerar o papel da educação na formação de leitores/ escritores críticos, versáteis, criativos e competentes.

Palavras-chave: práticas de leitura e escrita; tecnologias de informação e comunicação; computadores; estudantes do ensino médio; contexto sociocultural; pesquisa qualitativa

The substitution of printed practices and the appropriation of digital practices: a study of students of the technological baccalaureate learning to use computers at school Presents a qualitative research on the literacy practices of eight dyads of high school students, whom use the computer to accomplish their school tasks. The article analyses literacy events recorded in audio and videotape from a sociocultural perspective. It reveals that the students develop different literacy practices according to the kind of production and knowledge of softwares needed to accomplished their school tasks. It concludes that the new technologies of communication provide access to worlds of multiple ways of reading and writing, based on those we already know, but that education should not omit its role in the formation of critical and competent readers and creative and versatile writers; after all, computers do not teach how to read and write electronically.

Key-words: literacy practices; ICT; computers; high school students; sociocultural approach; qualitative research

Marcos Cezar de Freitas

Economia e educação: a contribuição de Álvaro Vieira Pinto para o estudo histórico da tecnologia Este artigo analisa a contribuição de Álvaro Vieira Pinto para os estudos de economia e educação. Seu conceito de trabalho tecnologicamente elaborado pode ser reconhecido como resultado de uma profunda investigação sobre as relações humanas que encontramos na "cultura da economia". Seu caminho teórico até os escritos de Marx aponta uma capacidade erudita de relacionar educação e emancipação política com a história da tecnologia.

Palavras-chave: economia; educação; tecnologia; cultura

Economy and education: Álvaro Vieira Pinto's contribution to historical studies on technology This paper analyses Álvaro Vieira Pinto's contribution to studies on economy and education. His concept of technologically elaborated work should be understood as the result of profound research into human relations which we find in the "culture of economics". His theoretical encounter with Marx's writings reveals an erudite capacity to relate education and political emancipation with the history of technology.

Key-words: economy; education; technology; culture

Economía y educación: la contribución de Álvaro Vieira Pinto para el estudio histórico de la tecnología

Este artículo analiza la contribución de Álvaro Vieira Pinto para los estudios de economía y educación. Su concepto de trabajo tecnológicamente elaborado puede ser reconocido como resultado de una profunda investigación sobre las relaciones humanas que encontramos en la "cultura de la economía". Su camino teórico hasta los escritos de Marx, muestran una capacidad erudita de relacionar educación y emancipación política con la historia de la tecnología.

Palabras claves: economía; educación; tecnología; cultura

Ana Waleska P. C. Mendonça, Libânia Nacif Xavier, Vera Lucia Alves Breglia, Miriam Waidenfeld Chaves, Maria Teresa Cavalcanti de Oliveira, Cecília Neves Lima, Pablo S. M. Bispo dos Santos

Pragmatismo e desenvolvimentismo no pensamento educacional brasileiro dos anos de 1950/1960 $\mathrm{O}$ artigo analisa as formas de apropriação do ideário da Escola Nova no Brasil, particularmente do pragmatismo deweyano, nos anos de 1950/1960. Parte-se do pressuposto de que a ideologia desenvolvimentista que pontuou o debate em torno da reestruturação econômica, política e social do país nessas duas décadas constituiu-se em um solo fértil para a retomada e a expansão do ideário pragmatista entre os educadores brasileiros, articulando-se, de forma al- 
gumas vezes até contraditória, com essa ideologia. O foco do nosso trabalho é a produção bibliográfica do grupo de educadores que se articulava em torno de Anísio Teixeira, à época diretor do Instituto Nacional de Estudos Pedagógicos (INEP), órgão vinculado ao Ministério da Educação e Cultura (MEC). De uma forma geral, pode-se afirmar que a apropriação do pragmatismo deweyano, nesse contexto, deu-se numa tripla perspectiva: o pragmatismo como método científico, implicando uma determinada concepção de ciência, particularmente das ciências sociais, com ênfase na aplicação do conhecimento científico na solução dos problemas de ordem prática; como modo de vida democrático; e como sinônimo de experimentalismo, no âmbito da escola. Palavras-chave: pragmatismo; desenvolvimentismo; pensamento educacional brasileiro; história da educação; política científica.

Pragmatism and developmentalism in Brazilian educational thought in the 1950's and 1960's

This article proposes to analyse some aspects of the appropriation of New

School thinking in Brazil, particularly Deweyan pragmatism, in the 1950's and 1960's. The analysis is based on the assumption that the developmentalist ideology which punctuated the debate on the economic, political and social restructuring of the country during these two decades constituted a fertile ground for the return and expansion of pragmatist thinking amongst Brazilian educators, articulating itself, sometimes in contradictory ways, with this ideology. The focus of this analysis is on the writings of that group of educators which circulated around the figure of Anísio Teixeira, at the time director of the National Institute for Pedagogic Studies (INEP), an organ linked to the Ministry of Education and Culture
(MEC). In general, could be stated that the Deweyan pragmatism

appropriation, in this context, happened according to tree perspectives: the pragmatism as cientific method, presupposing a certain conception of science, specially of social science, focusing on the applications of scientific knowledge on the solution of practical problems; as democratic style of life; and as synonym of experimentalism, in school environment.

Key-words: Pragmatism;

developmentalism; Brazilian

educational thought; history of

education; scientific policy

Pragmatismo y desenvolvimiento en el pensamiento educacional brasileño de los años 1950/1960

El artículo analiza las formas de apropiación del ideario de la Escuela Nueva en Brasil, particularmente del pragmatismo deweyano, en los años de 1950/1960. Se parte de la suposición de que la ideología desenvolvimentista que marcó el debate en torno de la reestructuración económica, política y social del país, en esas dos décadas, se costituyó en un suelo fértil para la retomada y la expansión del ideario pragmatista entre los educadores brasileños, articulándose de forma algunas veces hasta contradictoria, con esa ideología. El foco de nuestro trabajo es la producción bibliográfica del grupo de educadores que se articulaban en torno de Anísio Teixeira, en la época era director del Instituto Nacional de Estudios Pedagógicos (INEP), órgano vinculado al Ministerio de Educación y Cultura (MEC). De forma general se puede afirmar que la apropiación del

pragmatismo deweyano, en ese contexto, se dió en una triple perspectiva: el pragmatismo como método científico, implicando en una determinada concepción de ciencia, particularmente de las ciencias sociales, con énfasis en la aplicación del conocimiento científico en la solución de los problemas de orden práctica; como modo de vida democrático, y como sinónimo de experimentalismo, en el ámbito de la escuela.

Palabras claves: pragmatismo; desenvolvimentismo; pensamiento educacional brasileño; historia de la educación, política científica

Maria Cristina Soares de Gouvêa e Mônica Yumi Jinzenji

Escolarizar para moralizar: discursos sobre a educabilidade da criança pobre (1820-1850)

$\mathrm{O}$ artigo busca analisar os discursos sobre a educação da infância pobre presentes na província mineira na primeira metade do século XIX, investigando as concepções sobre a educabilidade da criança dos estratos sociais inferiores e seu papel na formação de uma nação civilizada. Esta criança era representada como possuindo faculdades mentais e qualidades morais diferenciadas das crianças dos estratos superiores, fruto de sua pertinência social, a serem reparadas pela educação escolar. Assim, definia-se um projeto de escolarização voltado para esse segmento da população, fundado na instrução, circunscrita ao ler, escrever e contar, e principalmente na educação moral, condição de formação de um adulto civilizado.

Palavras-chave: história da infância; história da educação; infância pobre

Education as a process of moralisation: discourses on the educability of poor children (18201850)

This paper analyses the discourse on the education of poor children which was present in the Province of Minas Gerais during the first decades of the $19^{\text {th }}$ century. It discusses the conceptions concerning the possibilities of educating poor children and the importance of education for the creation of a civilised 